
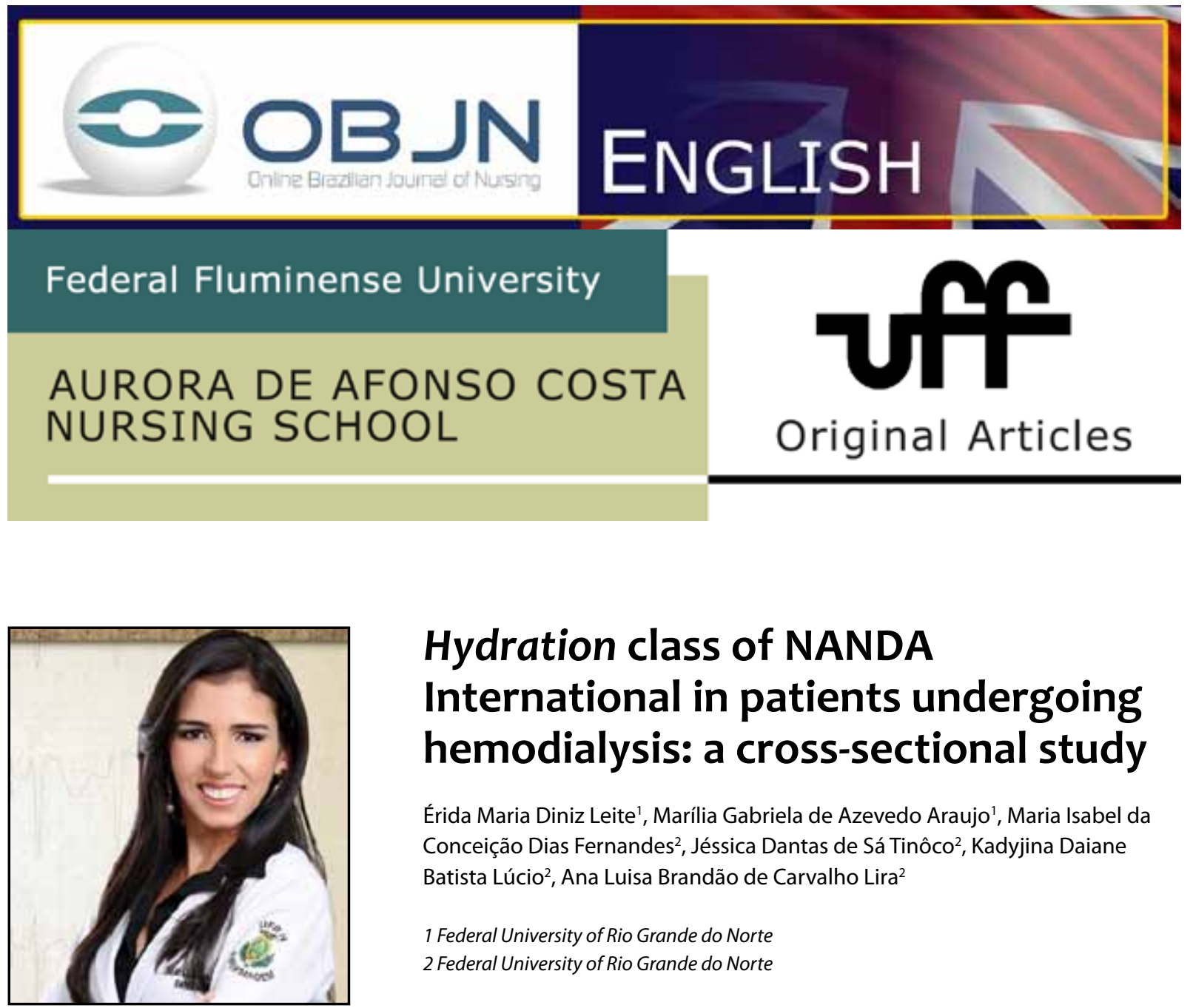

\title{
Hydration class of NANDA International in patients undergoing hemodialysis: a cross-sectional study
}

\author{
Érida Maria Diniz Leite', Marília Gabriela de Azevedo Araujo', Maria Isabel da \\ Conceição Dias Fernandes², Jéssica Dantas de Sá Tinôco², Kadyjina Daiane \\ Batista Lúcio², Ana Luisa Brandão de Carvalho Lira² \\ 1 Federal University of Rio Grande do Norte \\ 2 Federal University of Rio Grande do Norte
}

\begin{abstract}
Aim: to analyze the association of nursing diagnoses of the Hydration class of NANDA International and its components in hospitalized patients undergoing hemodialysis. Method: This is a cross-sectional study involving 50 patients at a university hospital in a city in northeastern Brazil. The diagnoses inference was performed by specialist nurses. The analysis was made through the use of descriptive and inferential statistics. The study was approved by the Ethics Committee under Opinion 392,535. Results: of the six diagnoses obtained, two were associated with its components involving an excessive volume of liquid with the following features: pulmonary congestion, edema and adventitious breath sounds, and the willingness to improve the fluid balance with an expressed desire to increase it. Discussion: the identified associations are related to the volume of fluid, and are constantly changing in the investigated patients. Conclusion: The volume of excessive liquids and the willingness to improve the fluid balance showed a significant association with some of its components.
\end{abstract}

Descriptors: Nursing Diagnosis; Signs and Symptoms; Fluid Therapy; Renal Dialysis. 


\section{INTRODUCTION}

The Nursing Process (NP) is an instrument responsible for articulating and evaluating the assistance provided. It allows the collection of data that will guide the nursing diagnoses and nursing decision-making concerning the indications of these diagnoses, and the development of targets and interventions in order to achieve the goals of care $^{(1)}$.

The NP is organized into five stages: data collection or nursing history, nursing diagnosis (ND), planning, implementation, and evaluation of the care provided. Nurses are responsible for leading the implementation and evaluation of this process and, in a private way, identifying the diagnosis and prescriptions of the actions ${ }^{(2)}$.

The ND is defined as a clinical judgment of an individual, family or community response to real or potential health problems in a given health/disease process, and is the basis for the screening of nursing interventions in the search for positive health outcomes ${ }^{(3)}$.

For the organization of ND, professionals use a variety of taxonomies responsible for organizing the relevant diagnostic concepts in their dominions. Among the most commonly-used taxonomies in the context of diagnostics, we can highlight the NANDA International(4,5,6).

The taxonomy of NANDA International is divided into 13 areas which are then divided into classes $^{(5)}$. Among these, we highlight the domain Nutrition and the class Hydration for individuals suffering with renal dysfunction who present frequent problems inherent to this class, as stated in the literature ${ }^{(7-8)}$ in the form of risk of electrolyte imbalance, excessive fluid volume and risk of fluid volume imbalance.

From this perspective, it is understood that a major function of the kidneys is to control the volume and composition of body fluids; therefore, the gain and loss of water and electrolytes are coordinated by the renal system. Thus, with the loss of kidney function, the individual begins to accumulate fluid, electrolytes and nitrogen excreta, requiring an artificial organ ${ }^{(9)}$. Therefore, renal replacement therapy (RRT) may be used, and hemodialysis is the most common therapy in Brazil $^{(10)}$.

In this context, the hospitalized patients on hemodialysis must be strictly monitored, especially by the nursing staff, bearing in mind the amount of time needed for this. The role of nurses as part of this team stands out because this is the professional responsible for identifying nursing problems and for tracing the related interventions, enabling the resolution of the problems identified in the patients. In this area of knowledge, technical and intellectual skills are especially needed - nursing diagnoses versus nephrology - to provide quality nursing care that is free of errors ${ }^{(11)}$.

Amongst the knowledge needed, clinical reasoning for establishing nursing diagnoses should be emphasized. For this, studies that assist in the establishment of the defining characteristics most frequently found in patients with kidney disease are important, as they facilitate the diagnostic inference process on the part of nurses in this area of knowledge.

The defining characteristics are considered reliable clues that help nurses to trace diagnostics correctly, ensuring their presence or absen$\mathrm{ce}^{(12)}$. Moreover, a study ${ }^{(13)}$ reports that the survey of these indicators enables the outlining of the main problems present in the studied patients, providing better planning and direction in terms of nursing care.

Therefore in this study, we consider it relevant to establish the characteristics of the Hydration class in terms of its high prevalence that shows increased association with the diagnoses, in order to contribute to the inference process of nephrologist nurses. Question: What clinical 
indicators present a significant association with the nursing diagnoses of the class Hydration? The study aims to analyze the association of nursing diagnoses of the class Hydration of NANDA International and its components in hospitalized patients undergoing hemodialysis.

\section{METHOD}

This is a cross-sectional study in the dialysis sector of a university hospital in northeastern Brazil. The study population consisted of 210 patients who underwent hemodialysis at this unit between January 2012 and January 2013, based on the computerized system used in the hospital.

The sample was determined based on the calculation for the finite population, considering: a level of confidence of $95 \%(Z a=1.96) ; a$ sampling error of $12 \%$; the size of the population of 210 people; and, as for the prevalence of the event, a conservative value of $50 \%$ was considered, there not being found a study that has estimated the nursing diagnoses prevalence of the domain Nutrition of NANDA International in terms of hemodialysis patients. Thus, the result was a sample of 50 patients selected for convenience, consecutively.

Data were collected between December 2013 and May 2014. The inclusion criteria were being admitted to the university hospital; being a patient with chronic kidney disease; undergoing hemodialysis in that hospital; aged over 18 years; being conscious and oriented. The exclusion criteria were being pregnant and undergoing hemodialysis in that hospital using external services and staff.

The data collection instruments were an interview form and a physical examination covering the defining characteristics, related factors/risks of nursing diagnoses present in that class. It has been validated in terms of content and appearance by two expert teachers in nephrology and the systematization of nursing care. To facilitate the collection, an application in Microsoft Office Excel 2010, containing the instrument's questions and also the scale system used with the support of a touch screen function, was developed.

Data were collected by the researcher and two scientific initiation scholarship students in the last year of the nursing course who had been previously trained. The training consisted of a six-hour's course that addressed topics such as anamnesis, investigative methods, ectoscopy, and water changes experienced by kidney patients undergoing hemodialysis and the nursing diagnoses of the class Hydration. Furthermore, the scholars were trained to operate the instrument in a digital format.

The data obtained were organized in 50 spreadsheets of Microsoft Office Excel 2010 software with the aim of supporting clinical reasoning, and establishing the defining characteristics, related factors/diagnostic risk of the class Hydration that are present and absent in each investigated patient.

Subsequently, in the period from July to August 2014, there was a diagnostic inference by experts, including an initial training and subsequent evaluation of the diagnostic capacity of six experts in the field of the systematization of nursing care and nephrology ${ }^{(14)}$.

The training consisted of interactive lectures, lasting three hours, on the nursing diagnoses of the domain Nutrition of NANDA International and on the main nutritional changes identified in kidney patients undergoing hemodialysis. The evaluation of the diagnostic ability of the experts took place through the use of 12 fictitious clinical cases, randomly distributed among the experts at three different times, totaling 36 ratings. The cases addressed defining characteristics, and 
related and risk factors of the domain Nutrition. Finally, we applied the Kappa test through the IBM SPSS Statistic software version 20.0 for Windows to verify the reliability of the answers of the experts in each of the three times that the case was evaluated. Thus, the three experts who had the highest scores were selected as diagnosticians.

The diagnosticians received the 50 worksheets in Microsoft Office Excel 2010. They analysed these for the presence or absence of nursing diagnoses of the class Hydration for each patient in the study. The responses of the three diagnosticians were compared and, in the event of disagreement, we applied the rule of the majority, considering this diagnosis when two of the three diagnosticians identified it as being present.

Data analysis was undertaken with the use of IBM SPSS Statistic software version 20.0, generating descriptive mean and standard deviation data for the quantitative variables and the absolute and relative frequencies for nominal variables. In terms of inferential data analysis, the verification of a statistical association between the components of each nursing diagnosis of the Hydration class with its referred diagnosis was carried out through the use of the chi-square test and Fisher's exact test. Thus, in terms of the statistical significance of the specified tests, a level of $5 \%(p<0.05)$ was adopted. It is noteworthy that the nursing diagnoses with prevalence higher than $50 \%$ were used in patients for the implementation of the association tests.

The study was approved by the Research Ethics Committee of the institution under Opinion No. 392,535 and CAAE 18710613.4.00005537. The participants expressed their acceptance with regard to contributing to the study by signing an Instrument of Consent.

\section{RESULTS}

According to the demographic data, most patients were female (62\%), light dark skin (68\%), living with a partner (54\%), religious practitioners (80\%) and provided beneficiaries or retired (62\%). The average age was 47.55 years, with a median of five years of study and 1.5 of the minimum wage in terms of family income.

The nursing diagnoses of the Hydration class presented the following prevalence in the studied sample: risk of electrolyte imbalance (100\%); excessive volume of liquid (90\%); improved liquid equilibrium potential (86\%); risk of deficient liquid volume (76\%); risk of fluid volume imbalance (44\%) and deficient liquid volume (2\%).

Table 1 shows the association between nursing diagnoses of the class Hydration and its components, as well as their prevalence.

Table 1 - Distribution of the association among nursing diagnoses of the class Hydration and their components. Natal, 2015.

\begin{tabular}{|c|c|c|}
\hline \multicolumn{3}{|c|}{ Excessive volume of liquid } \\
\hline Defining characteristics & $\%$ & $\begin{array}{l}\text { Valor } \\
\text { p1 }\end{array}$ \\
\hline Change in blood pressure & 100 & - \\
\hline Anxiety & 96 & 0,192 \\
\hline Azotemia & 96 & 1 \\
\hline Decreased hemoglobin & 92 & 0,353 \\
\hline Decreased hematocrit & 88 & 0,487 \\
\hline Altered electrolytes & 78 & 1 \\
\hline Edema & 78 & $0,000^{*}$ \\
\hline Intake greater than the output & 78 & 0,301 \\
\hline Pulmonary congestion & 62 & $0,005^{*}$ \\
\hline Adventitious breath sounds & 62 & $0,005^{*}$ \\
\hline Change in breathing pattern & 60 & 0,377 \\
\hline \multicolumn{3}{|l|}{ Related factors } \\
\hline $\begin{array}{l}\text { Compromised regulatory mechanis- } \\
\text { ms }\end{array}$ & 100 & - \\
\hline \multicolumn{3}{|c|}{ Improved liquid equilibrium potential } \\
\hline Defining characteristics & $\%$ & $\begin{array}{l}\text { Valor } \\
\text { p1 }\end{array}$ \\
\hline $\begin{array}{l}\text { Expressed desire to increase the fluid } \\
\text { balance }\end{array}$ & 80 & $0,000^{*}$ \\
\hline Mucous membranes hydrated & 76 & 0,337 \\
\hline
\end{tabular}

Leite EMD, Araujo MGA, Fernandes MICD, Tinôco JDS, Lúcio KDB, Lira ALBC. Hydrationclass of NANDA International in patients undergoing hemodialysis: a cross-sectional study. Online braz j nurs [internet] 2015 Dec [cited year month day]; 14 (suppl.):515-24. Available from: http://www.objnursing.uff.br/index.php/nursing/article/view/4892 


\begin{tabular}{|c|c|c|}
\hline Without excessive thirst & 70 & 0,659 \\
\hline Good tissue turgor & 52 & 1 \\
\hline \multicolumn{3}{|c|}{ Risk of deficient liquid volume } \\
\hline Risk factors & $\%$ & $\begin{array}{c}\text { Valor } \\
\text { p1 }\end{array}$ \\
\hline Failure in the regulatory mechanisms & 100 & - \\
\hline Fluid loss by abnormal pathways & 90 & 0,582 \\
\hline Knowledge deficiency & 74 & 1 \\
\hline
\end{tabular}

Subtitle: Fisher exact test 1; Components presenting statistically significant association with diagnosis *. Source: authors

The diagnosis of excessive fluid volume was significantly associated with the indicators edema, pulmonary congestion and adventitious breath sounds. The diagnosis of nursing provision for improved liquid equilibrium potential was significantly associated with the indicator expressed desire to increase the fluid balance. The diagnosis risk of deficient fluid volume was not significantly associated with its components.

Finally, the risk of electrolyte imbalance diagnosis could not be subjected to statistical association against the prevalence of $100 \%$ presented by it. Its risk factors showed variable frequency: renal impairment (100\%); impaired regulatory mechanisms (100\%); and excessive volume of liquid (74\%).

\section{DISCUSSION}

As for the socio-demographic profile, the study in question features a majority of female patients, of brown color, living with a partner, practicing some religion and which was financially supported by retirement or other benefits. Another study of nursing diagnosis in patients undergoing dialysis treatment shows similar rates ${ }^{(15)}$.

The last dialysis census showed that most dialysis patients are in the 19 to 64 year age group, corroborating the average age of the patients ${ }^{(10)}$. As for the educational level, the population surveyed had a median of five years of study, equivalent to incomplete primary education - similar to the results of another study ${ }^{(16)}$.

Regarding the defining characteristics edema $(P=0.000)$, pulmonary congestion $(p=0.005)$ and adventitious breath sounds $(p=0.005)$, which were significantly associated with the diagnosis of excessive liquid volume, another study confirms the relationship of these components with excess liquid and renal disease in such patients ${ }^{(15)}$. Another survey on the diagnostic profile of kidney patients undergoing hemodialysis reveals this diagnosis as prevalent in the patients under consideration $^{(7)}$.

Corroborating the study cited above, a research into the accuracy of the components of excessive fluid volume in patients undergoing hemodialysis, asserts that this diagnosis has a prevalence of $82 \%$. Among the features that present statistical association are agitation, pulmonary congestion, jugular venous distension, edema, altered electrolytes, weight gain in a short period, intake greater than output and breath sounds. The component edema is responsible for increasing the chances of the occurrence of the diagnosis by a factor of three ${ }^{(15)}$.

Edema is presented as a significant feature regarding the diagnosis of excessive liquid volume in terms of renal failure patients on hemodialysis. This assertion indicates that, when this characteristic is present, there is a high probability that the referred diagnosis is also present ${ }^{(15)}$. In this respect, it is known that the edema is related to fluid accumulation in the individual's body, such as in the interstitial spaces as a result of impairment in the renal function in terms of filtering electrolytes, including sodium, the main volume controller of liquid compartments ${ }^{(17)}$. 
In addition to the edema, other features such as pulmonary congestion and the presence of adventitious breath sounds are signs that suggest the accumulation of fluid in these patients ${ }^{(15)}$. Pulmonary congestion results in impaired gas exchange that relates the secondary hypoxemia to a ventilation-perfusion imbalance and pulmonary ede$\mathrm{ma}^{(18)}$. In addition, the congestion can cause respiratory distress to patients, as they may have changes in their breathing pattern. These changes are responsible for important pathophysiological changes in volume and lung capacity, increasing the severity of the condition of the dialysis patients ${ }^{(19)}$.

Regarding the change in blood pressure, which is identified in $100 \%$ of the patients analyzed, a study asserts that the high interdialytic weight gain has a negative impact on the blood pressure of renal patients, and hypotension is one of the most frequent complications in these patients during hemodialysis, and is related to the excessive removal of fluids ${ }^{(9)}$.

As for anxiety, a survey involving renal patients demonstrates in its findings that this characteristic becomes the major predictor of musculoskeletal, respiratory, cardiovascular, immunological, neurosensory and gastrointestinal problems. It emphasizes that these patients become vulnerable to developing anxiety disorders, making necessary a precautionary approach to mitigate this characteristic ${ }^{(20)}$.

The characteristics of azotemia, decreased hemoglobin, and decreased hematocrit are inherent in patients with kidney disease when evaluating its pathophysiology. In this sense, azotemia is a common sign of renal dysfunction, characterized by the accumulation of urea and creatinine in the blood as a result of renal impairment. The condition for the maintenance of life is the realization of a substitution therapy such as hemodialysis, aiming to excrete these substances that are toxic to the body ${ }^{(9)}$.

Concerning the hematocrit and decreased hemoglobin, it is considered that anemia is a common result in renal patients undergoing dialysis because of the deficit of erythropoietin produced by the kidney ${ }^{(21)}$. Moreover, the reduction of such a component is worsened due to gastrointestinal bleeding condition, malnutrition, surgical procedures, losses during the collection of material for examination, and dialysis ${ }^{(22)}$.

Finally, among the high-frequency defining characteristics of the excessive volume of liquid, we can also mention the changed electrolytes and intake higher than output. Kidney patients have problems arising from the decrease in the glomerular filtration rate (GFR) due to the accumulation of fluids in the body induced by an intake greater than output and electrolyte imbalances that, in the long term, increase the risk for cardiovascular diseases ${ }^{(9)}$.

It is noteworthy that, despite the hydrological imbalances evidenced by these patients in this study, the diagnosis improved liquid equilibrium potential was present, with emphasis on the feature expressed desire to increase the fluid balance $(p=0.000)$, which statistically was associated with the occurrence of the diagnosis. The research that has investigated the need for interaction between the patient and health team argues that patients on hemodialysis have better quality of life when accompanied by a multidisciplinary health team, which provides individual strategies for rehabilitation and self-sufficiency ${ }^{(21,23)}$.

The literature shows the importance of strictness as to the fluid restriction in the search for water balance control and the 
prevention of edema, as well as the activities aimed at education and guidance of these patients ${ }^{(16,21)}$. Adequate fluid intake is reflected by the gain in interdialytic weight. Patients should follow the guidelines of the National Kidney Foundation, which lays down an increase of $5 \%$ by weight between one hemodialysis session and another ${ }^{(21)}$.

Despite the fact that the ND risk of deficient liquid volume, which is defined as the risk of a reduction in intravascular, interstitial and/or intracellular fluids ${ }^{(5)}$, does not present a significant association with its indicators, it demonstrates characteristics with remarkable prevalence, due to the relationships presented in the literature. In this sense, the risk factor failure in the regulatory mechanisms, present in $100 \%$ of demands, and leads to the disorder between the intake and the output of fluids from the body. It is known that the kidneys regulate the volume of fluid in the body. However, failure compromises the entire homeostasis, causing great risk to the fluid balance(21).

The loss of liquid by abnormal pathways may be characterized by hemodialysis with a positive ultrafiltration in this study. The removal of excess fluid is one of the goals of the dialysis treatment, as well as metabolic waste removal. This treatment utilizes the mechanisms of diffusion and ultrafiltration, in a countercurrent flow which ensures the efficacy of dialysis. The fluid loss occurs by altering the hydrostatic pressure during the ultrafiltration, and through semipermeable membranes, per concentration gradient ${ }^{(9)}$.

With regard to knowledge deficiency, a survey reveals that the autonomy and adherence to the treatment on the part of the chronic kidney patient is not related to their level of education ${ }^{(24)}$. Therefore, the literature showed no association between knowledge deficiency and the patients' educational level, but commented on the lack of guidance on their illness and treatment regimen that should be offered by the health team. Another study points out the need for efforts in terms of health education in chronic renal patients in order to improve the self-management of the disease ${ }^{(25)}$.

The risk of electrolyte imbalance, featured in a hegemonic form in the investigated patients, had as risk factors, renal dysfunction, impaired regulatory mechanisms and an excessive volume of liquid. Another study confirms this finding by presenting this ND with high prevalence in a similar population, highlighting the risk factor excessive liquid volume $^{(26)}$. The other risk factors have an intrinsic relationship with chronic kidney disease, as previously reported.

\section{CONCLUSION}

The conclusion is that four nursing diagnoses of the class Hydration of the domain $\mathrm{Nu}$ trition of the International NANDA, presenting a prevalence above $50 \%$ in the study sample, were identified: risk of electrolyte imbalance; excessive liquid volume; improved fluid balance potential; and risk of deficient liquid volume.

Regarding the statistical relationships, only two ND were associated with its components, as in the case of the excess liquid volume with the components pulmonary congestion, edema, and adventitious breath sounds. In addition, the diagnosis improved fluid balance potential expressed a desire to increase the fluid balance.

Furthermore, among the ND identified in this study, it was observed that the majority refer to the volume of fluid, which is constantly changing in the investigated patients and 
which requires fast and accurate intervention by the nursing staff, as well as encouragement with regard to the control of liquid volume. In this sense, the recognition of diagnostics involving this problem and the factors that may influence its occurrence require precise nursing actions in terms of the control and prevention of the imbalance in the volume of liquid.

As a contribution, it is pointed out that studies dealing with the identification of nursing diagnoses and clinical indicators in specific types of patient allow the recognition of a diagnostic profile, assisting in the rapid identification of problems in similar patients.

As far as study limitations are concerned, we emphasize the fact that the research was developed in a hospital environment; it was restricted to patients hospitalized in hemodialysis; and only relates to those who underwent kidney replacement therapy such as hemodialysis, excluding other forms of such treatment. Thus, the results of this research cannot be extrapolated to studies with different patients.

\section{REFERENCES}

1. Guedes ES, Turrini RNT, Sousa RMC, Baltar VT, Cruz DALM. Attitudes of nursing staff related to the nursing process. Rev Esc Enferm USP [internet]. 2012 [Cited 2015 Apr 5]; 46(Esp):1307. Available from: http://www.scielo.br/pdf/ reeusp/v46nspe/19.pdf

2. Resolução $n^{\circ} 358$ do Conselho Federal Enfermagem, de 15 de outubro de 2009 (BR). Dispõe sobre a Sistematização da Assistência de Enfermagem e a implementação do Processo de Enfermagem em ambientes, públicos ou privados, em que ocorre o cuidado profissional de Enfermagem, e dá outras providências. 2009. [Cited 2015 Jun 10]. Available from:: <http://
www.portalcorenrs.gov.br/docs/Legislacoes/ legislacao_7a3914c30c09bb242f08c9f36a77 $6 f d d . p d f>$.

3. Conselho Federal de Enfermagem. Resolução COFEN no 358, de 15 de Outubro de 2009 - Dispõe sobre a Sistematização da Assistência de Enfermagem e a implementação do Processo de Enfermagem em ambientes, públicos ou privados, em que ocorre o cuidado profissional de Enfermagem, e dá outras providências. Brasília: COFEN; 2009.

4. Avant KC, Zeller RL, Zeller LD. Introdução às taxonomias: o que são e porque a enfermagem precisa delas. In: NANDA Internacional Inc; Herdman TH, Carvalho EC (Org.). PRONANDA - Programa de atualização em diagnósticos de enfermagem - Conceitos básicos. Porto Alegre: Artmed Panamericana; 2013. p. 11-28.

5. Herdman TH. Diagnósticos de Enfermagem da NANDA: definições e classificação - 2012/2014. 2. ed. Porto Alegre: Artmed; 2013.

6. Tastan S. Evidence for the existing American Nurses Association-recognized standardized nursing terminologies: A systematic review. International Journal of Nursing Studies. 2014; 51:1160-1170.

7. Frazão $C M F Q$, Medeiros $A B A$, Silva, FBBL, SÁ $J D$, Lira ALBC. Nursing diagnoses in chronic renal failure patients on hemodialysis. Acta paul enferm [internet]. 2014 [Cited 2015 Apr 5]; 27(1):40-3. Available from: http://www. scielo.br/pdf/ape/v27n1/pt_0103-2100ape-27-01-00040.pdf

8. Bezerra MLR, Ribeiro PRS, Sousa AA, Costa AIS, Batista TS. Diagnósticos de enfermagem conforme a teoria do autocuidado de orem para pacientes em tratamento hemodialítico. Rev Ciênc Ext [Internet]. 2012 [Cited 2015 May 10]; 8(1):60-81. Available from: http://ojs.unesp. br/index.php/revista_proex/article/view/533

9. Reddenna L, Basha SA, Reddy KSK. Dialysis Treatment: A comprehensive Description. Int J Pharm Sci Res [internet]. 2014[Cited 2015 Apr 10]; 3(1):1-13. Available from: http://connection.ebscohost.com/c/articles/94733739/ dialysis-treatment-comprehensive-description 10. Sociedade Brasileira de Nefrologia. Censo de Diálise 2013. São Paulo (SP), 2014. [Cited 2015 
Jun 10]. Available from: http://www.sbn.org. br/pdf/censo_2013-14-05.pdf.

11. Barbosa GS, Guimarões RM, Stipp MAC. Série histórica de custos com terapia de substituição renal no município do Rio de Janeiro (19952009). Esc Anna Nery. 2013; 17 (2):322 -7.

12. Aliti GB, Linhares JCC, Linch GFC, Ruschel KB, Rabelo ER. Sinais e sintomas de pacientes com insuficiência cardíaca descompensada: inferência dos diagnósticos de enfermagem prioritários. Rev gaúch enferm [Internet]. 2011 [Cited 2015 Apr 10]; 32 (3):590-5. Available from: http://www.scielo.br/pdf/rgenf/ v32n3/22.pdf

13. Saldanha EA, Silva FBBL, Sá JD, Fernandes MICD, Lira ALBC, Lopes MVO. Defining characteristics present in patients receiving post-operatory care after prostatectomy: a transversal study. Online braz $\mathrm{j}$ nurs [Internet]. 2013[Cited 2015 Jun 10]; 12 (2): 442-50. Available from: http://www.objnursing.uff.br/index. php/nursing/article/view/4072.

14. Lopes MVO, Silva V M, Araujo TL. Methods for establishing the accuracy of clinical indicators in predicting nursing diagnosis. Int J Nurs Knowl [Internet]. 2012[Cited 2015 Jun 10]; 23(3):134-9. Available from: http:// onlinelibrary.wiley.com/doi/10.1111/j.20473095.2012.01213.x/abstract

15. Fernandes MICD, Medeiros ABA, Macedo BM, Vitorino ABF, Lopes MVO, Lira ALBC. Prevalência do diagnóstico de enfermagem Volume de líquidos excessivo em pacientes submetidos à hemodiálise. Rev Esc Enferm USP [Internet]. 2014[Cited 2015 May 10]; 48(3):446-53. Available from: http://www.scielo.br/pdf/reeusp/ v48n3/pt_0080-6234-reeusp-48-03-446.pdf

16. Jafari F, Mobasheri M, Mirzaeian R. Effect of diet education on blood pressure changes and interdialytic weight in hemodialysis patients admitted in hajar hospital in shahrekord. Mater Sociomed [Internet]. 2014 [Cited 2015 Apr 5]; 26(4):228-30. Available from: http://www.ncbi. nlm.nih.gov/pmc/articles/PMC4272845/

17. Riella $M C$, Martins C. Nutrição e o Rim. 2. ed. Rio de Janeiro: Guanabara Koogan; 2013.

18. Cavalcanti ACD, Pereira JMV. Diagnósticos de enfermagem de pacientes com insuficiência cardíaca: revisão integrativa. Online braz j nurs [Internet]. 2014 [Cited 2015 Jun 10]; 13(1):11324. Available from: http://www.objnursing. uff.br/index.php/nursing/article/view/3916/ html_102.

19. Duarte J, Medeiros RF, Di Pietro T, Lopes TM. Alterações de volumes e capacidades pulmonares pré e pós-hemodiálise em insuficiência renal Crônica. J Health Sci Inst [Internet]. 2011 [Cited 2015 May 10]; 28(1):70-2. Available from: http://www.unip.br/comunicacao/ publicacoes/ics/edicoes/2011/01_jan-mar/ V29_n1_2011_p70-72.pdf

20. Perales-Montilla CM, Duschek S, Paso GAR. Influencia de los factores emocionales sobre el informe de síntomas somáticos en pacientes en hemodiálisis crónica: relevancia de la ansiedade. Nefrología [Internet]. 2013[Cited 2015 Jun 10]; 33(6): 816-25. Available from: http://scielo.isciii.es/scielo.php?script=sci_ar ttext\&pid=S021169952013000700009\&lan=pt

21. National Kidney Foundation, KDIGO, Kidney Disease Improving Global Outcomes. Am J Kidney Dis [Internet]. 2013 [Cited 2015 Apr 5]; 3(1):1-24. Available from: http://www.kidney-international.org.

22. Alves MAR, Gordan PA. Diangnóstico de anemia em pacientes portadores de doença renal crônica. J Bras Nefrol [Internet]. 2014 [Cited 2015 Apr 5]; 361 (1):9-12. Available from: http:// www.scielo.br/pdf/jbn/v36n1s1/0101-2800jbn-36-01-s1-0009.pdf

23. Dipp T, Silva VG, Baumgartem MC, Sturmer G, Plentz RDM. Intervenções interdisciplinares no cuidado ao paciente com doença renal crônica em Hemodiálise. Extendere [Internet]. 2013 [Cited 2015 Apr 5]; 2(1): 10-22. Available from: http://periodicos.uern.br/index.php/ extendere/article/view/775

24. Pinheiro J. Autonomia e aderência na pessoa com doença renal crônica. Rev. bioét [Internet]. 2011 [Cited 2015 May 5]; 19(1): 219-29. Available from: http://revistabioetica.cfm.org. br/index.php/revista_bioetica/article/viewFile/616/633

25. Lai AY, Ishikawa H, Kiuchi T, Mooppil N, Griva K.. Communicative and critical health literacy, and 
self-management behaviors in end-stage renal disease patients with diabetes on hemodialysis. Patient Educ Couns [Internet]. 2013 [Cited 2015 Jun 5]; 91: 221-7. Available from: http:// www.ncbi.nlm.nih.gov/pubmed/23357415

26. Dallé J, Lucena AF. Nursing diagnoses identified in hospitalized patients during hemodialysis. Acta Paul Enferm [Internet]. 2012 [Cited 2015 Jun 5]; 25(4):504-10. Available from: http://www.scielo.br/pdf/ape/v25n4/ en_04.pdf
All authors participated in the phases of this publication in one or more of the following steps, in According to the recommendations of the International Committee of Medical Journal Editors (ICMJE, 2013): (a) substantial involvement in the planning or preparation of the manuscript or in the collection, analysis or interpretation of data; (b) preparation of the manuscript or conducting critical revision of intellectual content; (c) approval of the versión submitted of this manuscript. All authors declare for the appropriate purposes that the responsibilities related to all aspects of the manuscript submitted to OBJN are yours. They ensure that issues related to the accuracy or integrity of any part of the article were properly investigated and resolved. Therefore, they exempt the OBJN of any participation whatsoever in any imbroglios concerning the content under consideration. All authors declare that they have no conflict of interest of financial or personal nature concerning this manuscript which may influence the writing and/or interpretation of the findings. This statement has been digitally signed by all authors as recommended by the ICMJE, whose model is available in http://www. objnursing.uff.br/normas/DUDE_eng_13-06-2013.pdf

Received: 07/16/2015

Revised: $11 / 23 / 2015$

Approved: 11/23/2015 